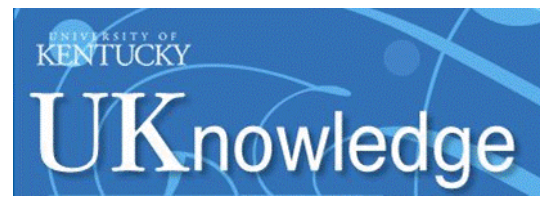

University of Kentucky

UKnowledge

Pharmacology and Nutritional Sciences Faculty

Publications

Pharmacology and Nutritional Sciences

2-19-2017

\title{
Calcium's Role as Nuanced Modulator of Cellular Physiology in the Brain
}

Hilaree N. Frazier

University of Kentucky, hilaree.frazier@uky.edu

Shaniya Maimaiti

University of Kentucky, snma224@g.uky.edu

Katie L. Anderson

University of Kentucky, katie.anderson2@uky.edu

Lawrence D. Brewer

University of Kentucky, lawrencebrewer@uky.edu

John C. Gant

University of Kentucky, jcgant2@uky.edu

Follow this and additional works at: https://uknowledge.uky.edu/pharmacol_facpub See next page for additional authors

Part of the Biochemistry, Biophysics, and Structural Biology Commons, Diseases Commons,

Neuroscience and Neurobiology Commons, and the Pharmacology, Toxicology and Environmental Health

Commons

Right click to open a feedback form in a new tab to let us know how this document benefits you.

\section{Repository Citation}

Frazier, Hilaree N.; Maimaiti, Shaniya; Anderson, Katie L.; Brewer, Lawrence D.; Gant, John C.; Porter, Nada M.; and Thibault, Olivier, "Calcium's Role as Nuanced Modulator of Cellular Physiology in the Brain" (2017). Pharmacology and Nutritional Sciences Faculty Publications. 82.

https://uknowledge.uky.edu/pharmacol_facpub/82

This Article is brought to you for free and open access by the Pharmacology and Nutritional Sciences at UKnowledge. It has been accepted for inclusion in Pharmacology and Nutritional Sciences Faculty Publications by an authorized administrator of UKnowledge. For more information, please contact UKnowledge@lsv.uky.edu. 


\section{Calcium's Role as Nuanced Modulator of Cellular Physiology in the Brain}

Digital Object Identifier (DOI)

https://doi.org/10.1016/j.bbrc.2016.08.105

\section{Notes/Citation Information}

Published in Biochemical and Biophysical Research Communications, v. 483, issue 4, p. 981-987.

(c) 2016 Elsevier Inc. All rights reserved.

This manuscript version is made available under the CC-BY-NC-ND 4.0 license

https://creativecommons.org/licenses/by-nc-nd/4.0/.

The document available for download is the author's post-peer-review final draft of the article.

\section{Authors}

Hilaree N. Frazier, Shaniya Maimaiti, Katie L. Anderson, Lawrence D. Brewer, John C. Gant, Nada M. Porter, and Olivier Thibault 
Published in final edited form as:

Biochem Biophys Res Commun. 2017 February 19; 483(4): 981-987. doi:10.1016/j.bbrc.2016.08.105.

\title{
Calcium's role as nuanced modulator of cellular physiology in the brain
}

\author{
Hilaree N Frazier, Shaniya Maimaiti, Katy L Anderson, Lawrence D Brewer, John C Gant, \\ Nada M Porter, and Olivier Thibault \\ UKMC, MS-313, Department of Pharmacology and Nutritional Sciences, University of Kentucky \\ Medical Center, 800 Rose Street, Lexington, KY 40536
}

\begin{abstract}
Neuroscientists studying normal brain aging, spinal cord injury, Alzheimer's disease (AD) and other neurodegenerative diseases have focused considerable effort on carefully characterizing intracellular perturbations in calcium dynamics or levels. At the cellular level, calcium is known for controlling life and death and orchestrating most events in between. For many years, intracellular calcium has been recognized as an essential ion associated with nearly all cellular functions from cell growth to degeneration. Often the emphasis is on the negative impact of calcium dysregulation and the typical worse-case-scenario leading inevitably to cell death. However, even high amplitude calcium transients, when executed acutely can alter neuronal communication and synaptic strength in positive ways, without necessarily killing neurons. Here, we focus on the evidence that calcium has a subtle and distinctive role in shaping and controlling synaptic events that underpin neuronal communication and that these subtle changes in aging or $\mathrm{AD}$ may contribute to cognitive decline. We emphasize that calcium imaging in dendritic components is ultimately necessary to directly test for the presence of age- or disease-associated alterations during periods of synaptic activation.
\end{abstract}

\section{Keywords}

afterhyperpolarization; familial Alzheimer's disease; insulin; estrogen; vitamin D; aging

\section{Introduction}

The role of calcium in neurodegenerative disorders has evolved significantly since early experiments showing hippocampal cell death in areas CA3 and CA1 in response to sustained synaptic activation of the perforant path in vivo [1]. These, and similar early experiments identified mechanisms of neuronal death reminiscent of calcium-induced necrosis, accompanied with blebbing of dendrites, retraction of processes, swelling of the soma and, ultimately, cellular death $[2 ; 3 ; 4]$. Framed in the context of a lengthy exposure to

Corresponding author: Olivier Thibault Ph.D. othibau@uky.edu.

Publisher's Disclaimer: This is a PDF file of an unedited manuscript that has been accepted for publication. As a service to our customers we are providing this early version of the manuscript. The manuscript will undergo copyediting, typesetting, and review of the resulting proof before it is published in its final citable form. Please note that during the production process errors may be discovered which could affect the content, and all legal disclaimers that apply to the journal pertain. 
glutamatergic neurotransmitters, these necrosis-associated events provided robust evidence that calcium could be a perpetuator of cell death. However, a combination of advanced reporter technologies and improved resolution in calcium imaging techniques have provided more recent evidence that calcium can be very subtle and localized to small cellular domains in response to subthreshold or suprathreshold transient synaptic depolarizations.

In the field of neuronal calcium dynamics, perhaps understandably, there appears to be a subjective preoccupation with the harmful effects of calcium dysregulation. However, a brief survey of the literature shows this is not well supported by the extent of the overall research in this area. Here we attempted to translate this idea in graphical form using data on published manuscripts across several fields. Examination of the literature between 1970 and 2015 (Fig. 1) shows the number of published manuscripts linking "brain" and "calcium" to a variety of other neurological changes in brain physiology, and pathology over the 45-year span. As a proportion of the total number of published manuscripts in all fields of science, the number of published work on brain calcium and physiology increased nearly 10 -fold between the years 1975 and 2000 (Fig 1A). It is interesting to note that whether looking at aging (Fig. 1B) or AD reports (Fig. 1C), physiological associations between brain and calcium represent the largest proportion of the overall scientific published work, while cell death, and pathology associated processes encompass a smaller body of work. We then determined what proportion of the manuscripts in the following categories: "calcium and brain" or "calcium and brain aging" or "calcium and brain and AD", focused on either physiology, cell death of pathology. The data obtained every 5 years were then averaged across the last 30 years (Fig.1D). While scientific output steadily increased over that period (e.g., calcium and brain return 826 manuscripts in 1985, and 2032 manuscripts in 2015), the proportion of physiologically-related manuscripts within each of the categories has remained greater ( $23 \%$ to 55\%, Fig 1D) compared to papers associating calcium in the brain with pathology or cell death ( $3 \%$ to $20 \%)$. A caveat should be added that we did not attempt to identify repeat manuscripts in the dataset (i.e., papers studying both physiology and pathology in relationship to calcium in the brain), thus, the numbers we report may be slightly inflated. Nevertheless, together, these data suggest that more studies have been published on associations between calcium and its physiological consequences rather than on how calcium influences cell death or pathophysiology.

Here we briefly review how age- and neurodegeneration-related changes in oxidation/ inflammation and certain hormones influence calcium dysregulation and impact cellular physiology. We also discuss the importance of focusing on the more subtle and localized calcium microdomains in neurons to better elucidate the impact of changes in calcium signaling in aging or in disease.

\section{Calcium dysregulation in Alzheimer's disease (AD) and AD models}

Early studies by several pioneering groups identified cellular calcium dysregulation as a major factor underlying functional alterations in aging tissues. These observations contributed to the formulation of the calcium hypothesis of brain aging and $\mathrm{AD}[5 ; 6]$. This work was followed by studies in human cortical cells showing that the $\beta$-amyloid peptide increases calcium levels at rest and in response to excitatory neurotransmitter release, 
resulting in compromised neuronal cell health [7]. Later studies in neurons harboring presenilin-1 (PS-1) mutations, a key player in A $\beta$ formation, helped identify several endoplasmic reticulum (ER) calcium handling proteins as targets of the genetic mutation [8]. Even human fibroblast and lymphoblasts display robust evidence of calcium dysregulation in AD $[9 ; 10 ; 11]$, suggesting the dysregulation may be "system-wide" rather than just CNScentered. Whether calcium dysregulation is a crucial initiator of the neuronal pathology, or a downstream event has been an open-ended question. Some studies have placed abnormal $\mathrm{Ca}^{2+}$ elevations downstream of PS-1 mutations $[12 ; 13 ; 14]$. On the other hand, ryanodine receptors and IP3 receptors have been identified as perpetrators of calcium dysregulation $[15 ; 16 ; 17 ; 18 ; 19 ; 20]$ and reducing IP3R expression in $3 \times \mathrm{Tg}$ mice attenuates $\mathrm{Ca}^{2+}$ signaling, $A \beta$ production and Tau hyperphosphorylation [20]. PS1 and PS2 mutations have also been found to directly target ER function, reducing ER calcium leaks, and overloading the ER with excess calcium [21; 22; 23]. Loss-of-function PS1 mutations are also associated with disturbed calcium-dependent lysosomal and autophagic pathways [24; 25$]$.

Interestingly, recent studies in animal models of AD using multiphoton calcium imaging techniques demonstrate that calcium overload may not be generalized to all neurons and could be dependent on proximity to a $\mathrm{A} \beta$ plaque [26; 27]; however, another study finds no association between distance from a plaque and neuronal calcium dysregulation [28]. In addition, neurofibrillary tangles do not appear to alter calcium levels or cellular excitability in the visual and somatosensory cortex [29], nor do they appear to alter calcium homeostasis in the cortex of animals displaying significant synapse loss [30].

Our understanding of the relationship between calcium dysregulation and AD in the brain still lacks clarity, and calcium dysregulation may also act upstream of $\mathrm{AD}$ pathology, whereby elevations in $\mathrm{Ca}^{2+}$ can increase production of oligomeric $\mathrm{A} \beta$ peptides [31]. As such, stabilizing ER calcium with dantrolene, a ryanodine receptor antagonist, restores normal synaptic function and plasticity and reduces amyloid load in the brains of $3 \times \mathrm{Tg} \mathrm{AD}$ mice [32] and knock-in FAD mice [33].

\section{Oxidative stress, inflammation, and calcium}

Calcium dysregulation tied to oxidative stress or inflammation in neuronal cells can have deleterious and long-lasting consequences resulting in calcium overload which may increase neuronal vulnerability under pathological conditions including AD [13; 19;34; 35; 36]. Indeed, sustained NMDA receptor activation or even reduced NMDA receptor inactivation can increase calcium elevations (immediate or delayed) which in turn, can produce reactive oxygen species (ROS) as a result of increased mitochondrial energy demands [37]. Still, it is not clear that the increase in ROS seen around the time of neuronal cell death with calcium overload is actually the cause of death or the consequence of the depolarized mitochondria [37].

ROS production in response to $A \beta$ peptides or other challenges in the brain $[38 ; 39]$ is well known to alter protein function [40; 41], and recently has also been shown to directly alter calcium channels [42; 43]. Still, the threshold (if there is one) to induce these devastating signaling pathways and the relationship to $\mathrm{Ca}^{2+}$ levels in vivo has been as difficult to identify as the targets of the oxidative stressors in the brain [44]. The poor clinical 
therapeutic translation seen in $\mathrm{AD}$ patients taking anti-oxidative therapies may be due to the fact that the precise targets are still unknown [45].

Brain inflammation, mediated by numerous cytokines (TNF-alpha, AIF, JNK) is common across brain aging and AD studies $[46 ; 47 ; 48 ; 49]$ and has been linked to calcium dysregulation. This calcium dysregulation, in turn has been shown to have consequences for synaptic plasticity [50; 51]. Calcium dysregulation alters the balance between LTP and LTD presumably through changes in the activation of select phosphatases and kinases $[52 ; 53 ; 54$; 55; 56]. However, this relationship has never been tested in vivo or with sufficient spatial or temporal resolution to address calcium dynamics in microdomains near postsynaptic densities at the exact sites of synaptic communication. Given the complex structure of postsynaptic densities in dendritic spines which includes ion channels, anchoring proteins, kinases and phosphatases $[57 ; 58 ; 59 ; 60 ; 61]$, this is a particularly important challenge that can only be surmounted with higher resolution microscopy that allows for measures of very controlled calcium rises during synaptic activation. Studies using tissue homogenates may be missing the impact of inflammation on calcium microdomains and the resulting synaptic processes.

At least one aspect of the association between oxidant/ inflammatory stressors and calcium dysregulation that has not received enough attention is whether different thresholds of dysregulation result in select activation of downstream pathways and/or different outcomes [7; 62; 63]. For example, it is not clear whether several repeated calcium events of smaller amplitudes (i.e., ministrokes) are as impactful as a single, large amplitude event (i.e., TBI, stroke). Also unclear, is whether the sensitivity of millisecond calcium cellular events to oxidant/inflammatory stressors changes across the lifespan.

\section{The impact of disappearing hormones in the brain of aged animals may alter calcium homeostasis}

While oxidative stress and inflammatory processes appear able to hasten calcium dysregulation with age, several endogenous steroid hormones including vitamin $\mathrm{D}$, estrogen and insulin seem capable of redressing this dysregulation. We have shown that both vitamin $\mathrm{D}$ and estrogen alter L-VGCC activity and calcium-dependent processes. Vitamin D (1,25 dihydroxvitamin D3) reduces L-VGCC currents probably due to reductions in both $\mathrm{Ca}_{\mathrm{v}} 1.2$ and $\mathrm{Ca}_{\mathrm{v}} 1.3$ expression in primary hippocampal cultures [64]. This reduction in current activity was also found in CA1 hippocampal neurons and was correlated with an age-related reduction in the slow afterhyperpolarization (sAHP) which would affect neuronal excitability [65]. Further, long-term treatment (6 months) of rats beginning at mid-age (12 months) with high vitamin D (10,000 IU cholecalciferol/ Kg rodent diet) showed improved spatial memory performance on the Morris water maze challenge. Thus, it appears that interfering with calcium homeostasis through pathways that are capable of increasing vitamin $\mathrm{D}$ receptor activation in the brain, may be a therapeutically meaningful strategy to preserve cognitive function in age and perhaps $\mathrm{AD}$.

Another hormone, estradiol, has also been shown to modulate L-VGCC expression and activity in hippocampal neurons and in GnRH related cells [66; 67]. Interestingly, in both of 
these cell types estradiol decreased $\mathrm{Ca}_{\mathrm{v}} 1.3$ expression but not $\mathrm{Ca}_{\mathrm{v}} 1.2$. In addition to affecting the expression of the L-VGCC subunit estradiol also modulates L-VGCC activity via a rapid mechanism that results in an increase in calcium influx through L-VGCCs in neurons and other cell lines $[68 ; 69 ; 70]$. This rapid pathway was proposed to be part of a neuroprotective pathway; whether it also functions to regulate physiological processes such as the sAHP is unknown. Nevertheless, the genomic mechanism appears to reduce L-VGCC activity but the rapid mechanism increases L-VGCC activity. This suggests the possibility that L-VGCC channel expression and calcium influx are dynamically regulated by estradiol, and as we and others have previously shown, can be altered in aging [66; 71].

Another recently identified hormone modulator of L-VGCC function in the brain is insulin. While investigating new mechanisms by which certain antidiabetic compounds can reduce calcium channel function and the AHP in hippocampal cells [72; 73], we also recently uncovered the acute and significant actions of insulin on the SAHP [74; 75]. By causing a significant reduction in the AHP, we predict insulin may be able to enhance cellular excitability in aging and offset cognitive decline. Indeed, several clinical studies have provided robust evidence that increasing brain insulin availability through intranasal delivery of the hormone is able to enhance recall in young subjects [76; 77] or MCI patients [78; 79; 80]. Similarly, we have shown beneficial effects of intranasal insulin on memory recall in aged animals in the Morris water maze [74]. Surprisingly, both young healthy subjects and $\mathrm{AD}$ patients appear to benefit equally from intranasal insulin. At least in the case of $\mathrm{AD}$, the intranasal administration is presumed to compensate for the reduced insulin signaling. Collectively, these results also suggest insulin signaling may be working differently in young $v s$ aged brains. Irrespective, this work lends further support to continue therapeutic efforts attempting to maintain insulin signaling in the brain of the elderly population in order to offset cognitive decline with age or with AD.

In light of these studies, it is tempting to speculate that perhaps vitamin $\mathrm{D}$, estrogen or insulin signaling are all compromised in the aged brain which may contribute to the development of dementia, and that increasing the availability of receptors for these hormones, or the levels of these hormones in the brain could combat cognitive decline in aging. Further, while it would seem that redressing calcium dyshomeostasis may be a pivotal approach to facilitate successful brain aging. However, more direct tests of this hypothesis are required, and investigating how these hormones regulate $\mathrm{Ca}^{2+}$ pathways will provide a framework on which to build new pharmacological approaches to combat cognitive decline in aging.

\section{Cellular calcium transients have a dendritic origin}

Nearly 20 years ago, imaging and electrophysiological approaches were used to derive new information on the complexity of dendritic actions and how neuronal output could be modified by key ion channels along the dendritic tree [81;82;83]. These findings culminated in the identification of different calcium sources along dendrites, main apical arbors, spines and shafts $[84 ; 85 ; 86 ; 87 ; 88 ; 89]$. The dendrite is the site for synaptic inputs where integration of signals from different areas of the brain occurs. As a result of action potential firing and the subsequent neurotransmitter release, small, albeit significant calcium 
changes are seen in the dendrite and more specifically, the spines of neurons. There, the more subtle role of calcium in controlling encoding and dendritic excitability through local calcium transients is now becoming clear, and includes measures in behaving animals [90; 91; 92; 93; 94; 95; 96]. In field CA1, primary hippocampal neurons are able to integrate signals coming from distal inputs from the entorhinal cortex, and more proximal inputs emitting from area CA3. At least part of this integration is mediated by newly identified dendritic calcium plateau potentials in vivo [97]. These short-lived dendritic calcium transients can help drive complex spike output in the main pyramidal neurons of the hippocampus by inactivating sodium channels, enhancing LTP [98] and thereby enhancing firing from coincident inputs in different areas of the brain. This complexity is only beginning to be elucidated in the dendrites of young or adult animals and this level of spatial and temporal resolution has not yet been achieved in animal models of aging or AD.

With the exception of a few additional studies, very little is known about dendritic calcium transients, their spatial and temporal integration, or about the presence and role of back propagating action potentials in apical dendrites in models of aging [99; 100]. Furthermore, these studies did not address changes in cellular cytoarchitecture/ morphology with age, its potential impact on physiology, nor did they study the impact of age-related changes in calcium sources on synaptic plasticity or activation. However, more progress along these lines has been made in animal models of AD. Using genetically-encoded calcium indicators to monitor calcium in spines of cultured neurons from mutant presenilin mice (M146V), recent evidence shows the presence of alterations in stromal interaction molecule 2 function (STIM2; a key regulator of store-operated calcium entry) [101; 102]. In these studies, the authors suggest that the loss of mushroom spines is mediated by the loss of the stabilizing effect of STIM2 on spines, and perhaps occurs in response to elevations in ER calcium levels during aging or in $\mathrm{AD}[14 ; 54 ; 103]$. Such studies are helping to identify new pharmaceutical targets and are highlighting new areas of focus in neuroscience.

Work using calcium imaging tools to focus on downstream consequences of calcium overload in AD models has helped shift the attention away from calcium-mediated cell death, and instead emphasize calcium-mediated changes in dendritic morphology, cellular excitability, network activity and plasticity. The first direct in vivo evidence showing that elevated $\mathrm{Ca}^{2+}$ in cortical dendrites is dependent on the presence of $\mathrm{A} \beta$ plaque deposition was recently identified in an AD animal model. Somewhat surprisingly, it was not the presenilin mutation, but rather, the APP mutation which was found to be associated with calcium dysregulation in aged mice [27]. Further, in these APP mutants (17-20 months old), proximity to the plaque was shown to heighten $\mathrm{Ca}^{2+}$ dysregulation. In another in vivo study using double transgenic mice, imaging from hippocampal CA1 neuronal somata also provided evidence of $\mathrm{Ca}^{2+}$ overload, but at much earlier ages (1-2 months) and prior to plaque deposition. However, a role for soluble amyloid still exists as calcium transients and hippocampal excitability were elevated upon application of $A \beta$ dimmers [26]. In both studies, thus it appears that some form of amyloid $\beta$ may be responsible for inducing neuronal calcium dysregulation.

Greater spatial and temporal resolutions are currently being implemented in the study of neuroscience following the discovery of genetically-encoded calcium indicators $[104 ; 105$; 
106]. These indicators have the advantage of being fast reporters which can be targeted to specific cellular compartments like the ER and the mitochondria [107; 108]. Studies investigating changes in calcium homeostasis using large arrays of cells are also now providing new in vivo results, but only in a limited number of studies in AD models [27; 29; 109]. High resolution in vivo calcium imaging using pulsed lasers capable of generating longer wavelengths will provide important information along these lines.

\section{New (and old) intricacies of calcium dysregulation with aging}

Calcium is not always increased in aging and or in AD. Our lab has published evidence of reduced L-type $\mathrm{Ca}^{2+}$ currents in the aged APP/PS1 mouse [110]. Years ago, Lamour's lab showed that calcium dysregulation did not translate well across different strains of rats [111]. Similarly, the Griffith lab also has reported that depending on L-type calcium channel subunits present, increases in L-type currents are not always seen with aging in basal forebrain neurons [112], and are often met with significant increases in calcium buffering capacity $[113 ; 114 ; 115]$. Recently, it was also shown that while more calcium enters the plasma membrane of an aged CA1 pyramidal neuron [100; 116], a corresponding increase in buffering balances this influx up to a point where calcium overload occurs [100]. Of interest, in a study of normal brain aging, we have identified that aged CA1 pyramidal neurons which typically display larger $\mathrm{Ca}^{2+}$-dependent afterhyperpolarizations when triggered postsynaptically, show significantly reduced hyperpolarization (e.g., enhanced hyperexcitability) compared to young animals, when stimulated synaptically across physiologically relevant frequencies $(3-50 \mathrm{~Hz})$ [117]. It is not yet clear that this form of hyperpolarization in the hippocampus with age during synaptic activity is dependent on calcium. It would be surprising if it were not, as stimulation at $7 \mathrm{~Hz}$ produces greater calcium in the soma [118] and dendrites [99; 100] in the aged animal. Given the importance of synaptic communication, stimulation protocols that approximate physiological patterns of activity may need to be studied further with aging and in AD-related neurodegeneration.

\section{Overall}

That changes in intracellular calcium levels occur with age and in Alzheimer's type dementia or in other neurodegenerative conditions is not new. As we have known for some time, calcium can be a sophisticated orchestrator of fine moment-by-moment events, or a deadly hammer that can overload mitochondria and other calcium buffering systems. Currently, there is greater appreciation for how calcium is able to shape synaptic events that underpin neuronal communication. However, in aging and $\mathrm{AD}$, it is unclear the extent to which dendritic $\mathrm{Ca}^{2+}$ sources are modified. Clearly, associations between an animal's behavioral phenotype, electrophysiological characterization across multiple hippocampal subfields and regions (i.e., dorsal vs. ventral), network activity and sensitivity to hormones, all need further investigation to understand how calcium sensitive targets are modified in the context of aging. Perhaps insights from these types of studies will allow us to view calcium dysregulation in aging and $\mathrm{AD}$ as more than just a destructive force, but instead, allow us to pave the way for novel therapeutic approaches that focus on these more nuanced changes and their effects on neuronal physiology. 


\section{Acknowledgments}

This work was supported by NIH grants AG033649; AG004542; AG020251. We want to thank Dr. Philip Landfield for his helpful discussions, comments and guidance.

\section{References}

1. Olney JW, deGubareff T, Sloviter RS. "Epileptic" brain damage in rats induced by sustained electrical stimulation of the perforant path. II. Ultrastructural analysis of acute hippocampal pathology. Brain Res Bull. 1983; 10:699-712. [PubMed: 6871738]

2. Ankarcrona M, Dypbukt JM, Bonfoco E, Zhivotovsky B, Orrenius S, Lipton SA, Nicotera P. Glutamate-induced neuronal death: a succession of necrosis or apoptosis depending on mitochondrial function. Neuron. 1995; 15:961-973. [PubMed: 7576644]

3. Choi DW. Glutamate neurotoxicity in cortical cell culture is calcium dependent. Neurosci Lett. 1985; 58:293-297. [PubMed: 2413399]

4. Sattler R, Charlton MP, Hafner M, Tymianski M. Distinct influx pathways, not calcium load, determine neuronal vulnerability to calcium neurotoxicity. J Neurochem. 1998; 71:2349-2364. [PubMed: 9832133]

5. Khachaturian ZS. Calcium, membranes, aging, and Alzheimer's disease. Introduction and overview. Ann N Y Acad Sci. 1989; 568:1-4.

6. Landfield PW. 'Increased calcium-current' hypothesis of brain aging. Neurobiol Aging. 1987; 8:346347. [PubMed: 3627350]

7. Mattson MP. Calcium as sculptor and destroyer of neural circuitry. Exp Gerontol. 1992; 27:29-49. [PubMed: 1499683]

8. Mattson MP, Guo Q, Furukawa K, Pedersen WA. Presenilins, the endoplasmic reticulum, and neuronal apoptosis in Alzheimer's disease. J Neurochem. 1998; 70:1-14. [PubMed: 9422341]

9. Ito E, Oka K, Etcheberrigaray R, Nelson TJ, McPhie DL, Tofel-Grehl B, Gibson GE, Alkon DL. Internal $\mathrm{Ca} 2+$ mobilization is altered in fibroblasts from patients with Alzheimer disease. Proc Natl Acad Sci U S A. 1994; 91:534-538. [PubMed: 8290560]

10. Gibson GE, Zhang H, Toral-Barza L, Szolosi S, Tofel-Grehl B. Calcium stores in cultured fibroblasts and their changes with Alzheimer's disease. Biochim Biophys Acta. 1996; 1316:71-77. [PubMed: 8672553]

11. Cheung KH, Mei L, Mak DO, Hayashi I, Iwatsubo T, Kang DE, Foskett JK. Gain-of-function enhancement of IP3 receptor modal gating by familial Alzheimer's disease-linked presenilin mutants in human cells and mouse neurons. Sci Signal. 2010; 3:ra22. [PubMed: 20332427]

12. Leissring MA, Akbari Y, Fanger CM, Cahalan MD, Mattson MP, LaFerla FM. Capacitative calcium entry deficits and elevated luminal calcium content in mutant presenilin-1 knockin mice. $\mathrm{J}$ Cell Biol. 2000; 149:793-798. [PubMed: 10811821]

13. LaFerla FM. Calcium dyshomeostasis and intracellular signalling in Alzheimer's disease. Nat Rev Neurosci. 2002; 3:862-872. [PubMed: 12415294]

14. Zhang H, Sun S, Herreman A, De Strooper B, Bezprozvanny I. Role of presenilins in neuronal calcium homeostasis. J Neurosci. 2010; 30:8566-8580. [PubMed: 20573903]

15. Stutzmann GE, Smith I, Caccamo A, Oddo S, Laferla FM, Parker I. Enhanced ryanodine receptor recruitment contributes to $\mathrm{Ca} 2+$ disruptions in young, adult, and aged Alzheimer's disease mice. $\mathrm{J}$ Neurosci. 2006; 26:5180-5189. [PubMed: 16687509]

16. Chakroborty S, Goussakov I, Miller MB, Stutzmann GE. Deviant ryanodine receptor-mediated calcium release resets synaptic homeostasis in presymptomatic $3 \times \mathrm{Tg}$-AD mice. J Neurosci. 2009; 29:9458-9470. [PubMed: 19641109]

17. Chan SL, Mayne M, Holden CP, Geiger JD, Mattson MP. Presenilin-1 mutations increase levels of ryanodine receptors and calcium release in PC12 cells and cortical neurons. J Biol Chem. 2000; 275:18195-18200. [PubMed: 10764737]

18. Stutzmann GE, Caccamo A, LaFerla FM, Parker I. Dysregulated IP3 signaling in cortical neurons of knock-in mice expressing an Alzheimer's-linked mutation in presenilin1 results in exaggerated 
Ca2+ signals and altered membrane excitability. J Neurosci. 2004; 24:508-513. [PubMed: 14724250]

19. Smith IF, Hitt B, Green KN, Oddo S, LaFerla FM. Enhanced caffeine-induced Ca2+ release in the $3 \times \mathrm{Tg}$-AD mouse model of Alzheimer's disease. J Neurochem. 2005; 94:1711-1718. [PubMed: $16156741]$

20. Shilling D, Muller M, Takano H, Mak DO, Abel T, Coulter DA, Foskett JK. Suppression of InsP3 receptor-mediated $\mathrm{Ca} 2+$ signaling alleviates mutant presenilin-linked familial Alzheimer's disease pathogenesis. J Neurosci. 2014; 34:6910-6923. [PubMed: 24828645]

21. Tu H, Nelson O, Bezprozvanny A, Wang Z, Lee SF, Hao YH, Serneels L, De Strooper B, Yu G, Bezprozvanny I. Presenilins form ER Ca2+ leak channels, a function disrupted by familial Alzheimer's disease-linked mutations. Cell. 2006; 126:981-993. [PubMed: 16959576]

22. Nelson O, Supnet C, Liu H, Bezprozvanny I. Familial Alzheimer's disease mutations in presenilins: effects on endoplasmic reticulum calcium homeostasis and correlation with clinical phenotypes. $\mathrm{J}$ Alzheimers Dis. 2010; 21:781-793. [PubMed: 20634584]

23. Das HK, Tchedre K, Mueller B. Repression of transcription of presenilin-1 inhibits gammasecretase independent ER $\mathrm{Ca}(2)(+)$ leak that is impaired by FAD mutations. J Neurochem. 2012; 122:487-500. [PubMed: 22607268]

24. Lee JH, McBrayer MK, Wolfe DM, Haslett LJ, Kumar A, Sato Y, Lie PP, Mohan P, Coffey EE, Kompella U, Mitchell CH, Lloyd-Evans E, Nixon RA. Presenilin 1 Maintains Lysosomal Ca(2+) Homeostasis via TRPML1 by Regulating vATPase-Mediated Lysosome Acidification. Cell Rep. 2015; 12:1430-1444. [PubMed: 26299959]

25. McBrayer M, Nixon RA. Lysosome and calcium dysregulation in Alzheimer's disease: partners in crime. Biochem Soc Trans. 2013; 41:1495-1502. [PubMed: 24256243]

26. Busche MA, Chen X, Henning HA, Reichwald J, Staufenbiel M, Sakmann B, Konnerth A. Critical role of soluble amyloid-beta for early hippocampal hyperactivity in a mouse model of Alzheimer's disease. Proc Natl Acad Sci U S A. 2012; 109:8740-8745. [PubMed: 22592800]

27. Kuchibhotla KV, Goldman ST, Lattarulo CR, Wu HY, Hyman BT, Bacskai BJ. Abeta plaques lead to aberrant regulation of calcium homeostasis in vivo resulting in structural and functional disruption of neuronal networks. Neuron. 2008; 59:214-225. [PubMed: 18667150]

28. Briggs CA, Schneider C, Richardson JC, Stutzmann GE. beta amyloid peptide plaques fail to alter evoked neuronal calcium signals in APP/PS1 Alzheimer's disease mice. Neurobiol Aging. 2013; 34:1632-1643. [PubMed: 23337342]

29. Kuchibhotla KV, Wegmann S, Kopeikina KJ, Hawkes J, Rudinskiy N, Andermann ML, SpiresJones TL, Bacskai BJ, Hyman BT. Neurofibrillary tangle-bearing neurons are functionally integrated in cortical circuits in vivo. Proc Natl Acad Sci U S A. 2014; 111:510-514. [PubMed: 24368848]

30. Kopeikina KJ, Wegmann S, Pitstick R, Carlson GA, Bacskai BJ, Betensky RA, Hyman BT, SpiresJones TL. Tau causes synapse loss without disrupting calcium homeostasis in the rTg4510 model of tauopathy. PLoS ONE. 2013; 8:e80834. [PubMed: 24278327]

31. Itkin A, Dupres V, Dufrene YF, Bechinger B, Ruysschaert JM, Raussens V. Calcium ions promote formation of amyloid beta-peptide (1-40) oligomers causally implicated in neuronal toxicity of Alzheimer's disease. PLoS ONE. 2011; 6:e18250. [PubMed: 21464905]

32. Chakroborty S, Briggs C, Miller MB, Goussakov I, Schneider C, Kim J, Wicks J, Richardson JC, Conklin V, Cameransi BG, Stutzmann GE. Stabilizing ER Ca2+ channel function as an early preventative strategy for Alzheimer's disease. PLoS ONE. 2012; 7:e52056. [PubMed: 23284867]

33. Zhang H, Liu J, Sun S, Pchitskaya E, Popugaeva E, Bezprozvanny I. Calcium signaling, excitability, and synaptic plasticity defects in a mouse model of Alzheimer's disease. J Alzheimers Dis. 2015; 45:561-580. [PubMed: 25589721]

34. Supnet C, Bezprozvanny I. Neuronal calcium signaling, mitochondrial dysfunction, and Alzheimer's disease. J Alzheimers Dis. 2010; 20(Suppl 2):S487-S498. [PubMed: 20413848]

35. Green KN, Demuro A, Akbari Y, Hitt BD, Smith IF, Parker I, LaFerla FM. SERCA pump activity is physiologically regulated by presenilin and regulates amyloid beta production. J Cell Biol. 2008; 181:1107-1116. [PubMed: 18591429] 
36. Supnet C, Bezprozvanny I. Presenilins function in ER calcium leak and Alzheimer's disease pathogenesis. Cell Calcium. 2011; 50:303-309. [PubMed: 21663966]

37. Connolly NM, Prehn JH. The metabolic response to excitotoxicity - lessons from single-cell imaging. J Bioenerg Biomembr. 2015; 47:75-88. [PubMed: 25262286]

38. Mark RJ, Hensley K, Butterfield DA, Mattson MP. Amyloid beta-peptide impairs ion-motive ATPase activities: evidence for a role in loss of neuronal Ca2+ homeostasis and cell death. $\mathrm{J}$ Neurosci. 1995; 15:6239-6249. [PubMed: 7666206]

39. Aliev G, Obrenovich ME, Reddy VP, Shenk JC, Moreira PI, Nunomura A, Zhu X, Smith MA, Perry G. Antioxidant therapy in Alzheimer's disease: theory and practice. Mini Rev Med Chem. 2008; 8:1395-1406. [PubMed: 18991755]

40. Butterfield DA, Dalle-Donne I. Redox proteomics. Antioxid Redox Signal. 2012; 17:1487-1489. [PubMed: 22671972]

41. Wang X, Michaelis EK. Selective neuronal vulnerability to oxidative stress in the brain. Front Aging Neurosci. 2010; 2:12. [PubMed: 20552050]

42. Patel R, Sesti F. Oxidation of ion channels in the aging nervous system. Brain Res. 2016

43. Gorlach A, Bertram K, Hudecova S, Krizanova O. Calcium and ROS: A mutual interplay. Redox Biol. 2015; 6:260-271. [PubMed: 26296072]

44. Aliev G, Priyadarshini M, Reddy VP, Grieg NH, Kaminsky Y, Cacabelos R, Ashraf GM, Jabir NR, Kamal MA, Nikolenko VN, Zamyatnin AA Jr, Benberin VV, Bachurin SO. Oxidative stress mediated mitochondrial and vascular lesions as markers in the pathogenesis of Alzheimer disease. Curr Med Chem. 2014; 21:2208-2217. [PubMed: 24372221]

45. Sheng H, Chaparro RE, Sasaki T, Izutsu M, Pearlstein RD, Tovmasyan A, Warner DS. Metalloporphyrins as therapeutic catalytic oxidoreductants in central nervous system disorders. Antioxid Redox Signal. 2014; 20:2437-2464. [PubMed: 23706004]

46. McGeer EG, McGeer PL. Neuroinflammation in Alzheimer's disease and mild cognitive impairment: a field in its infancy. J Alzheimers Dis. 2010; 19:355-361. [PubMed: 20061650]

47. Blalock EM, Geddes JW, Chen KC, Porter NM, Markesbery WR, Landfield PW. Incipient Alzheimer's disease: microarray correlation analyses reveal major transcriptional and tumor suppressor responses. Proc Natl Acad Sci U S A. 2004; 101:2173-2178. [PubMed: 14769913]

48. Blalock EM, Grondin R, Chen KC, Thibault O, Thibault V, Pandya JD, Dowling A, Zhang Z, Sullivan P, Porter NM, Landfield PW. Aging-related gene expression in hippocampus proper compared with dentate gyrus is selectively associated with metabolic syndrome variables in rhesus monkeys. J Neurosci. 2010; 30:6058-6071. [PubMed: 20427664]

49. McGeer PL, McGeer EG. Polymorphisms in inflammatory genes and the risk of Alzheimer disease. Arch Neurol. 2001; 58:1790-1792. [PubMed: 11708985]

50. Sama DM, Norris CM. Calcium dysregulation and neuroinflammation: discrete and integrated mechanisms for age-related synaptic dysfunction. Ageing Res Rev. 2013; 12:982-995. [PubMed: 23751484]

51. Norris CM, Korol DL, Foster TC. Increased susceptibility to induction of long-term depression and long-term potentiation reversal during aging. J Neurosci. 1996; 16:5382-5392. [PubMed: 8757251]

52. Quintana AR, Wang D, Forbes JE, Waxham MN. Kinetics of calmodulin binding to calcineurin. Biochem Biophys Res Commun. 2005; 334:674-680. [PubMed: 16009337]

53. Klee CB. Concerted regulation of protein phosphorylation and dephosphorylation by calmodulin. Neurochem Res. 1991; 16:1059-1065. [PubMed: 1664495]

54. Foster TC. Calcium homeostasis and modulation of synaptic plasticity in the aged brain. Aging Cell. 2007; 6:319-325. [PubMed: 17517041]

55. Foster TC, Sharrow KM, Masse JR, Norris CM, Kumar A. Calcineurin links Ca2+ dysregulation with brain aging. J Neurosci. 2001; 21:4066-4073. [PubMed: 11356894]

56. Norris CM, Halpain S, Foster TC. Reversal of age-related alterations in synaptic plasticity by blockade of L-type Ca2+ channels. J Neurosci. 1998; 18:3171-3179. [PubMed: 9547225]

57. Murphy JG, Sanderson JL, Gorski JA, Scott JD, Catterall WA, Sather WA, Dell'Acqua ML. AKAP-anchored PKA maintains neuronal L-type calcium channel activity and NFAT transcriptional signaling. Cell Rep. 2014; 7:1577-1588. [PubMed: 24835999] 
58. Dell'Acqua ML, Smith KE, Gorski JA, Horne EA, Gibson ES, Gomez LL. Regulation of neuronal PKA signaling through AKAP targeting dynamics. Eur J Cell Biol. 2006; 85:627-633. [PubMed: 16504338]

59. Gorski JA, Gomez LL, Scott JD, Dell'Acqua ML. Association of an A-kinase-anchoring protein signaling scaffold with cadherin adhesion molecules in neurons and epithelial cells. Mol Biol Cell. 2005; 16:3574-3590. [PubMed: 15930126]

60. Zhang J, Shapiro MS. Activity-dependent transcriptional regulation of M-Type (Kv7) K(+) channels by AKAP79/150-mediated NFAT actions. Neuron. 2012; 76:1133-1146. [PubMed: 23259949]

61. Bal M, Zhang J, Hernandez CC, Zaika O, Shapiro MS. Ca2+/calmodulin disrupts AKAP79/150 interactions with KCNQ (M-Type) K+ channels. J Neurosci. 2010; 30:2311-2323. [PubMed: 20147557]

62. Nixon RA, Saito KI, Grynspan F, Griffin WR, Katayama S, Honda T, Mohan PS, Shea TB, Beermann M. Calcium-activated neutral proteinase (calpain) system in aging and Alzheimer's disease. Ann N Y Acad Sci. 1994; 747:77-91. [PubMed: 7847693]

63. Toescu EC, Verkhratsky A. The importance of being subtle: small changes in calcium homeostasis control cognitive decline in normal aging. Aging Cell. 2007; 6:267-273. [PubMed: 17517038]

64. Brewer LD, Thibault V, Chen KC, Langub MC, Landfield PW, Porter NM. Vitamin D hormone confers neuroprotection in parallel with downregulation of L-type calcium channel expression in hippocampal neurons. J Neurosci. 2001; 21:98-108. [PubMed: 11150325]

65. Brewer LD, Porter NM, Kerr DS, Landfield PW, Thibault O. Chronic 1alpha,25-(OH)2 vitamin D3 treatment reduces $\mathrm{Ca} 2+-$ mediated hippocampal biomarkers of aging. Cell Calcium. 2006; 40:277286. [PubMed: 16780945]

66. Brewer LD, Dowling AL, Curran-Rauhut MA, Landfield PW, Porter NM, Blalock EM. Estradiol reverses a calcium-related biomarker of brain aging in female rats. J Neurosci. 2009; 29:60586067. [PubMed: 19439583]

67. Farkas I, Sarvari M, Aller M, Okada N, Okada H, Liko I, Liposits Z. Estrogen receptor alpha and beta differentially mediate $\mathrm{C} 5 \mathrm{aR}$ agonist evoked $\mathrm{Ca} 2+$-influx in neurons through L-type voltagegated Ca2+ channels. Neurochem Int. 2012; 60:631-639. [PubMed: 22406418]

68. Wu TW, Wang JM, Chen S, Brinton RD. 17Beta-estradiol induced Ca2+ influx via L-type calcium channels activates the $\mathrm{Src/ERK} /$ cyclic-AMP response element binding protein signal pathway and BCL-2 expression in rat hippocampal neurons: a potential initiation mechanism for estrogeninduced neuroprotection. Neuroscience. 2005; 135:59-72. [PubMed: 16084662]

69. Kelly MJ, Ronnekleiv OK. A selective membrane estrogen receptor agonist maintains autonomic functions in hypoestrogenic states. Brain Res. 2013; 1514:75-82. [PubMed: 23535448]

70. Sarkar SN, Huang RQ, Logan SM, Yi KD, Dillon GH, Simpkins JW. Estrogens directly potentiate neuronal L-type Ca2+ channels. Proc Natl Acad Sci U S A. 2008; 105:15148-15153. [PubMed: 18815371]

71. Singh M, Simpkins JW, Bimonte-Nelson HA, Brinton RD. Window of opportunity for estrogen and progestin intervention in brain aging and Alzheimer's disease. Brain Res. 2013; 1514:1-2. [PubMed: 23726132]

72. Pancani T, Phelps JT, Searcy JL, Kilgore MW, Chen KC, Porter NM, Thibault O. Distinct modulation of voltage-gated and ligand-gated $\mathrm{Ca} 2+$ currents by PPAR-gamma agonists in cultured hippocampal neurons. J Neurochem. 2009; 109:1800-1811. [PubMed: 19453298]

73. Blalock EM, Phelps JT, Pancani T, Searcy JL, Anderson KL, Gant JC, Popovic J, Avdiushko MG, Cohen DA, Chen KC, Porter NM, Thibault O. Effects of long-term pioglitazone treatment on peripheral and central markers of aging. PLoS ONE. 2010; 5:e10405. [PubMed: 20454453]

74. Maimaiti S, Anderson KL, DeMoll C, Brewer LD, Rauh BA, Gant JC, Blalock EM, Porter NM, Thibault O. Intranasal Insulin Improves Age-Related Cognitive Deficits and Reverses Electrophysiological Correlates of Brain Aging. J Gerontol A Biol Sci Med Sci. 2016; 71:30-39. [PubMed: 25659889]

75. Pancani T, Anderson KL, Brewer LD, Kadish I, DeMoll C, Landfield PW, Blalock EM, Porter NM, Thibault O. Effect of high-fat diet on metabolic indices, cognition, and neuronal physiology in aging F344 rats. Neurobiol Aging. 2013; 34:1977-1987. [PubMed: 23545425] 
76. Brunner YF, Kofoet A, Benedict C, Freiherr J. Central insulin administration improves odor-cued reactivation of spatial memory in young men. J Clin Endocrinol Metab. 2015; 100:212-219. [PubMed: 25337926]

77. Freiherr J, Hallschmid M, Frey WH 2nd, Brunner YF, Chapman CD, Holscher C, Craft S, De Felice FG, Benedict C. Intranasal insulin as a treatment for Alzheimer's disease: a review of basic research and clinical evidence. CNS Drugs. 2013; 27:505-514. [PubMed: 23719722]

78. Craft S, Baker LD, Montine TJ, Minoshima S, Watson GS, Claxton A, Arbuckle M, Callaghan M, Tsai E, Plymate SR, Green PS, Leverenz J, Cross D, Gerton B. Intranasal insulin therapy for Alzheimer disease and amnestic mild cognitive impairment: a pilot clinical trial. Arch Neurol. 2012; 69:29-38. [PubMed: 21911655]

79. Reger MA, Watson GS, Frey WH 2nd, Baker LD, Cholerton B, Keeling ML, Belongia DA, Fishel MA, Plymate SR, Schellenberg GD, Cherrier MM, Craft S. Effects of intranasal insulin on cognition in memory-impaired older adults: modulation by APOE genotype. Neurobiol Aging. 2006; 27:451-458. [PubMed: 15964100]

80. Reger MA, Watson GS, Green PS, Baker LD, Cholerton B, Fishel MA, Plymate SR, Cherrier MM, Schellenberg GD, Frey Ii WH, Craft S. Intranasal Insulin Administration Dose-Dependently Modulates Verbal Memory and Plasma Amyloid-beta in Memory-Impaired Older Adults. J Alzheimers Dis. 2008; 13:323-331. [PubMed: 18430999]

81. Magee JC, Johnston D. A synaptically controlled, associative signal for Hebbian plasticity in hippocampal neurons. Science. 1997; 275:209-213. [PubMed: 8985013]

82. Markram H, Lubke J, Frotscher M, Sakmann B. Regulation of synaptic efficacy by coincidence of postsynaptic APs and EPSPs. Science. 1997; 275:213-215. [PubMed: 8985014]

83. Sejnowski TJ. The year of the dendrite. Science. 1997; 275:178-179. [PubMed: 8999546]

84. Regehr WG, Connor JA, Tank DW. Optical imaging of calcium accumulation in hippocampal pyramidal cells during synaptic activation. Nature. 1989; 341:533-536. [PubMed: 2797180]

85. Jaffe DB, Johnston D, Lasser-Ross N, Lisman JE, Miyakawa H, Ross WN. The spread of Na+ spikes determines the pattern of dendritic Ca2+ entry into hippocampal neurons. Nature. 1992; 357:244-246. [PubMed: 1350327]

86. Alford S, Frenguelli BG, Schofield JG, Collingridge GL. Characterization of $\mathrm{Ca} 2+$ signals induced in hippocampal CA1 neurones by the synaptic activation of NMDA receptors. J Physiol. 1993; 469:693-716. [PubMed: 8271224]

87. Yuste R, Denk W. Dendritic spines as basic functional units of neuronal integration. Nature. 1995; 375:682-684. [PubMed: 7791901]

88. Schiller J, Helmchen F, Sakmann B. Spatial profile of dendritic calcium transients evoked by action potentials in rat neocortical pyramidal neurones. J Physiol. 1995; 487(Pt 3):583-600. [PubMed: 8544123]

89. Segal M. Imaging of calcium variations in living dendritic spines of cultured rat hippocampal neurons. J Physiol. 1995; 486(Pt 2):283-295. [PubMed: 7473196]

90. Camire O, Topolnik L. Dendritic calcium nonlinearities switch the direction of synaptic plasticity in fast-spiking interneurons. J Neurosci. 2014; 34:3864-3877. [PubMed: 24623765]

91. Poolos NP, Johnston D. Dendritic ion channelopathy in acquired epilepsy. Epilepsia. 2012; 53(Suppl 9):32-40. [PubMed: 23216577]

92. Helmchen F, Tank DW. A single-compartment model of calcium dynamics in nerve terminals and dendrites. Cold Spring Harb Protoc. 2015; 2015:155-167. [PubMed: 25646507]

93. Araya R, Vogels TP, Yuste R. Activity-dependent dendritic spine neck changes are correlated with synaptic strength. Proc Natl Acad Sci U S A. 2014; 111:E2895-E2904. [PubMed: 24982196]

94. Hill DN, Varga Z, Jia H, Sakmann B, Konnerth A. Multibranch activity in basal and tuft dendrites during firing of layer 5 cortical neurons in vivo. Proc Natl Acad Sci U S A. 2013; 110:1361813623. [PubMed: 23904480]

95. Kim Y, Hsu CL, Cembrowski MS, Mensh BD, Spruston N. Dendritic sodium spikes are required for long-term potentiation at distal synapses on hippocampal pyramidal neurons. Elife. 2015; 4

96. Sheffield ME, Dombeck DA. Calcium transient prevalence across the dendritic arbour predicts place field properties. Nature. 2015; 517:200-204. [PubMed: 25363782] 
97. Bittner KC, Grienberger C, Vaidya SP, Milstein AD, Macklin JJ, Suh J, Tonegawa S, Magee JC. Conjunctive input processing drives feature selectivity in hippocampal CA1 neurons. Nat Neurosci. 2015; 18:1133-1142. [PubMed: 26167906]

98. Takahashi H, Magee JC. Pathway interactions and synaptic plasticity in the dendritic tuft regions of CA1 pyramidal neurons. Neuron. 2009; 62:102-111. [PubMed: 19376070]

99. Hemond P, Jaffe DB. Caloric restriction prevents aging-associated changes in spike-mediated Ca2+ accumulation and the slow after hyperpolarization in hippocampal CA1 pyramidal neurons. Neuroscience. 2005; 135:413-420. [PubMed: 16112472]

100. Oh MM, Oliveira FA, Waters J, Disterhoft JF. Altered calcium metabolism in aging CA1 hippocampal pyramidal neurons. J Neurosci. 2013; 33:7905-7911. [PubMed: 23637181]

101. Sun S, Zhang H, Liu J, Popugaeva E, Xu NJ, Feske S, White CL 3rd, Bezprozvanny I. Reduced synaptic STIM2 expression and impaired store-operated calcium entry cause destabilization of mature spines in mutant presenilin mice. Neuron. 2014; 82:79-93. [PubMed: 24698269]

102. Zhang H, Wu L, Pchitskaya E, Zakharova O, Saito T, Saido T, Bezprozvanny I. Neuronal StoreOperated Calcium Entry and Mushroom Spine Loss in Amyloid Precursor Protein Knock-In Mouse Model of Alzheimer's Disease. J Neurosci. 2015; 35:13275-13286. [PubMed: 26424877]

103. Gant JC, Sama MM, Landfield PW, Thibault O. Early and simultaneous emergence of multiple hippocampal biomarkers of aging is mediated by $\mathrm{Ca} 2+$-induced $\mathrm{Ca} 2+$ release. J Neurosci. 2006; 26:3482-3490. [PubMed: 16571755]

104. Pologruto TA, Yasuda R, Svoboda K. Monitoring neural activity and [Ca2+] with genetically encoded Ca2+ indicators. J Neurosci. 2004; 24:9572-9579. [PubMed: 15509744]

105. Chen TW, Wardill TJ, Sun Y, Pulver SR, Renninger SL, Baohan A, Schreiter ER, Kerr RA, Orger MB, Jayaraman V, Looger LL, Svoboda K, Kim DS. Ultrasensitive fluorescent proteins for imaging neuronal activity. Nature. 2013; 499:295-300. [PubMed: 23868258]

106. Dana H, Mohar B, Sun Y, Narayan S, Gordus A, Hasseman JP, Tsegaye G, Holt GT, Hu A, Walpita D, Patel R, Macklin JJ, Bargmann CI, Ahrens MB, Schreiter ER, Jayaraman V, Looger LL, Svoboda K, Kim DS. Sensitive red protein calcium indicators for imaging neural activity. Elife. 2016; 5

107. Qiu DL, Akemann W, Chu CP, Araki R, Knopfel T. Targeted optical probing of neuronal circuit dynamics using fluorescent protein sensors. Neurosignals. 2008; 16:289-299. [PubMed: 18635945]

108. Kotlikoff MI. Genetically encoded $\mathrm{Ca} 2+$ indicators: using genetics and molecular design to understand complex physiology. J Physiol. 2007; 578:55-67. [PubMed: 17038427]

109. Overk CR, Rockenstein E, Florio J, Cheng Q, Masliah E. Differential calcium alterations in animal models of neurodegenerative disease: Reversal by FK506. Neuroscience. 2015; 310:549_ 560. [PubMed: 26341908]

110. Thibault O, Pancani T, Landfield PW, Norris CM. Reduction in neuronal L-type calcium channel activity in a double knock-in mouse model of Alzheimer's disease. Biochim Biophys Acta. 2012; 1822:546-549. [PubMed: 22265986]

111. Potier B, Lamour Y, Dutar P. Cholinergic and non-cholinergic synaptic mechanisms in the aged rat hippocampus. Ann N Y Acad Sci. 1993; 695:236-240. [PubMed: 8239289]

112. Etheredge JA, Murchison D, Abbott LC, Griffith WH. Functional compensation by other voltagegated $\mathrm{Ca} 2+$ channels in mouse basal forebrain neurons with $\mathrm{Ca}(\mathrm{V}) 2.1$ mutations. Brain Res. 2007; 1140:105-119. [PubMed: 16364258]

113. Murchison D, Griffith WH. Age-related alterations in caffeine-sensitive calcium stores and mitochondrial buffering in rat basal forebrain. Cell Calcium. 1999; 25:439-452. [PubMed: 10579055]

114. Murchison D, Griffith WH. Calcium buffering systems and calcium signaling in aged rat basal forebrain neurons. Aging Cell. 2007; 6:297-305. [PubMed: 17517040]

115. Murchison D, McDermott AN, Lasarge CL, Peebles KA, Bizon JL, Griffith WH. Enhanced calcium buffering in F344 rat cholinergic basal forebrain neurons is associated with age-related cognitive impairment. J Neurophysiol. 2009; 102:2194-2207. [PubMed: 19675291]

116. Thibault O, Landfield PW. Increase in single L-type calcium channels in hippocampal neurons during aging. Science. 1996; 272:1017-1020. [PubMed: 8638124] 
117. Gant JC, Thibault O. Action potential throughput in aged rat hippocampal neurons: regulation by selective forms of hyperpolarization. Neurobiol Aging. 2009; 30:2053-2064. [PubMed: 18367293]

118. Thibault O, Hadley R, Landfield PW. Elevated postsynaptic [Ca2+]i and L-type calcium channel activity in aged hippocampal neurons: relationship to impaired synaptic plasticity. J Neurosci. 2001; 21:9744-9756. [PubMed: 11739583] 
- Dysregulated calcium is not only associated with cell death in aging or AD

- Improved resolution and reporter strategies need implementation in aging research

- Dendritic calcium imaging will provide insights into mechanisms of brain aging

- Hormonal influence over calcium regulation may be a promising therapeutic approach 

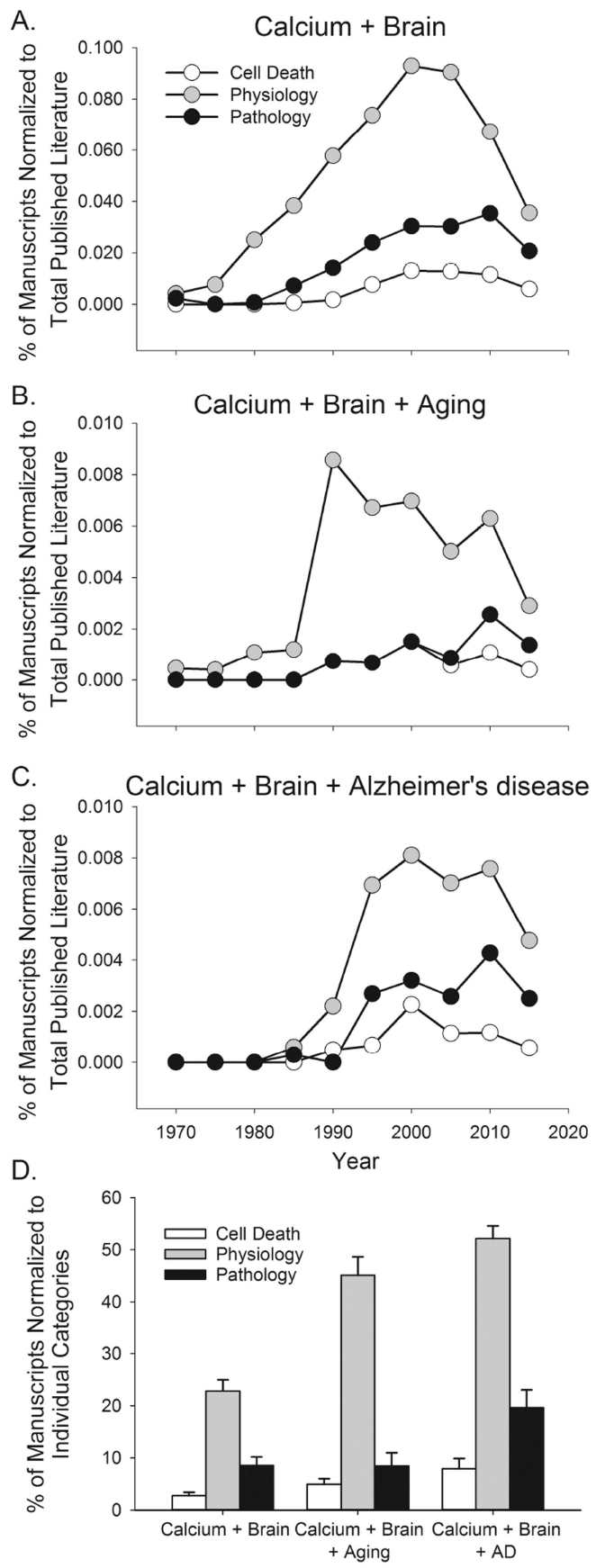

Figure 1.

Survey of the literature relating to calcium dysregulation in the brain. A PubMed search was performed with EndNote using the terms "calcium" and "brain" (A) or "calcium" and "brain" and "aging" (B), or "calcium" and "brain" and "Alzheimer's disease" $(\mathbf{C})$. The number of papers containing the combined keywords and an association with "cell death", "physiology", or "pathology" was obtained once every five years between the years 1970 and 2015 and was normalized to the total number of scientific publications that year. We then restricted the search to the past 30 years and collapsed the data across years and used 
the same search strategy. This time, we normalized the number of papers in cell death, physiology or pathology to the total number of papers within "calcium" and "brain" or "calcium" and "brain" and "aging", or "calcium" and "brain" and "Alzheimer's disease" is shown in (D). It is clear that a greater proportion of the literature focusing on calcium in the brain contains a majority of the work centered on physiological outcomes. 